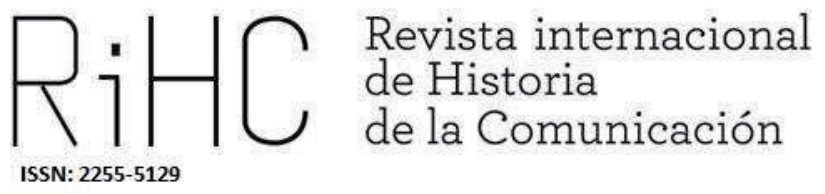

\title{
THE «BOLLETTINO DELLE BIBLIOTECHINE RURALI» OF ZIA MARIÚ: A CHILDREN'S MAGAZINE CALLED TO BUILD SOCIETY THROUGH BOOKS
}

El "Boletín de bibliotecas rurales" de zia Mariú: una revista infantil llamada a construir sociedad a través del libro.

DOI: http://dx.doi.org/10.12795/RiCH.2021.i17.05

Francesca Davida Pizzigoni

INDIRE, Italia

f.pizzigoni@indire.it

ORCID (D) 0000-0002-9117-4027 
Abstract: In the Italy of the early twentieth century, the initiative created by zia Mariù (Paola Lombroso) and promoted through its organ of dissemination "Bollettino delle bibliotechine rurali» manages to provide over 1000 rural schools with a small school library. This action, carried out through the active commitment of other children, on one hand has the power to affect the society, on the other hand initiating an action of great "active citizenship" by children and, finally, interrupting the condition of extreme poverty and marginality in which rural schools lived in. The article aims to present the initiative through the writings of zia Mariù herself and in particular through the pages of the "Bollettino delle bibliotechine rurali», identifying the role of this communication instrument compared to the success of the project.

Keywords: history of children's literature; civic education, rural school libraries, sources, active citizenship.

Resumen: En la Italia de principios del siglo XX, la iniciativa creada por zia Mariù (Paola Lombroso) y promovida a través de su órgano de difusión «Bollettino delle bibliotechine rurali» consigue dotar a más de 1000 escuelas rurales de una pequeña biblioteca escolar. Esta acción, realizada a través del compromiso activo de otros niños, por un lado tiene el poder de afectar a la sociedad, por otro inicia una acción de gran "ciudadanía activa" por parte de los niños y, finalmente, interrumpe la condición de pobreza extrema y marginalidad en la que vivían las escuelas rurales. El artículo pretende presentar la iniciativa a través de los escritos de la propia zia Mariù y en particular a través de las páginas del "Bollettino delle bibliotechine rurali», identificando el papel de este instrumento de comunicación frente al éxito del proyecto.

Palabras clave: historia de la literatura infantil, educación cívica, bibliotecas escolares rurales, fuentes, ciudadanía activa.

\section{Introduction}

It was the first decade of the twentieth century when zia Mariù manages to build a real business capable of involving thousands of active children throughout Italy in favor of other children. The project, in a nutshell, is to donate small libraries to rural schools, purchased not through donations, but through the direct commitment of other children who take action, according to their possibilities and abilities, to create small initiatives in favour of such libraries.

The idea was based on aspects as simple as powerful: communication skills; a «Bollettino delle bibliotechine rurali» to disseminate the project, update on its progress and to create what we would today call "community"; the book strenght and the pleasure of reading.

In reality, there was much more to it than that: a solid knowledge of society and of the Italian rural school; an unconditional trust in the abilities of children; the profound conviction of the importance of offering all children the opportunity to approach 
reading; an important cultural preparation combined with an unusual social-intellectual formation; a dense network of contacts.

As it is known, under the pseudonym zia Mariù hides Paola Carrara Lombroso (18711954), daughter of the famous anthropologist-criminologist Cesare Lombroso, author of texts for childhood, journalist and above all cultural organizer of initiatives aimed at children (Dolza, 1990). The article aims to reconstruct some of the peculiar features of this initiative so unique and so significant for Italy at the time through the study of the official organ of dissemination of the initiative itself, the «Bollettino delle bibliotechine rurali».

The studies until now devoted to the theme mainly deal with the preparatory phase of this initiative, analyzing the context in which it develops, namely that of the design and launch of the magazine for children «Corriere dei piccoli» (Fava, 2004).

Annother more recent point of view focused on the rediscovery of some products made by supporters of the zia Marilù Library project and specifically of four pop-up albums made by the teacher Luisa Terzi on the basis of children's books published by zia Mariù herself.

The aim of this article is to find out the characteristics of the success of zia Mariù's project through her writings. Moreover will be analyzed the stages of birth and development of this communication tool of the project, its structure and its contents. Finally, will be highlighted the peculiarities of the project that emerge through the pages of the Bulletin and that have contributed decisively to the success of the initiative.

\section{The working method}

The working method is based on primary sources, for instance those writings that Paola Lombroso dedicates to her initiative and above all tracing the copies of the «Bollettino delle bibliotechine rurali».

It is stored in the National Libraries of Turin and Florence and it represents an inexhaustible multidirectional source, which allows to frame the initiative in favour of rural schools in a wide and articulated context. Through the study of the pages of the "Bollettino delle bibliotechine rurali» will be outlined these possible lines of investigation that, although it cannot be addressed within this article, allow to fully grasp the magnitude of the initiative. At the same time, they underline the value of the «Bollettino delle bibliotechine rurali» itself in two different directions: a rich, articulated and powerful communication tool and at the same time a source for historical research. 
The bulletin was made in Turin and was about to be printed with variable periodicity and titles between January the 10th in 1912 and 1935. Its pages, of different number from time to time are around ten. The analysis will be confined here to the first years of publication of the Bulletin, since over time it will change its functions: with the advent of the First World War, as a matter of fact it will be devoted to other charitable actions to assist children and families in difficulty ${ }^{1}$. Starting from 1915 this trend is shown also through a new name of the Bulletin itself: besides "Bibliotechine rurali» were added "Child care" and "Ten for one" (where 10 for one means the commitment of ten children to collect the amount needed to help a child in a situation of distress). In addition to this there will be a forced setback linked to the rise of fascism which will increasingly seek to exercise direct control over education and culture and which will put under surveillance Paola Lombroso and her husband Mario Carrara, doctor and university professor, who refused devotion to fascism (Calcagni, 1977).

The analysis of the "Bollettino delle bibliotechine rurali» will be preceded by a short introduction that explains the context from which it was born, outlining the figure Paola Lombroso Carrara and the initiative that she has devised, of which the "Bollettino delle bibliotechine rurali» is mirror.

After the direct study of the Bulletin to identify the structure of this publication and to understand the content and information that allows us to grasp today for the benefit of historical research, we will discuss communication aspects that have certainly decreed the success of the "Bollettino delle bibliotechine rurali» itself and the initiative it promotes.

\section{Outcomes}

Paola Lombroso developed "interest in the world of childhood, psychology, pedagogy and children's literature" (Simone, 2020). Furthermore, she was inspired by her father's research and by the speeches of the intellectuals attending their home, marked by an anti-fascist thought, attentive to observe what was happening in the world and to analyze it. The social and political thinking of Paola Lombroso was also influenced by the figure of Anna Kulishoff, that leads her and her sister to a personal commitment in favor of society improvement and in particular of childhood (Dolza, 1990). The first initiative

1 To be precise, the study is based on the copies still available today of the Bulletin published between 1912 and 1915, equal to a corpus of 54 numbers. The temporal choice is dictated, as already mentioned in the text, the will to follow the original project of the Bulletin and the initiative of which it is a communication instrument without analysing the transformations of the project as a result of the needs related to the First World War (correspondence with soldiers, charitable works, childcare...) and shortly after the control exercised gradually more heavily by the fascist power. 
in favour of the workers' children, a kind of creative recreational after-school called «School and Family» dates back to 1896 (Babini, 2008).

It is preceded by the beginning of the long and fruitful relationship between Paola and the world of writing, with the first works dedicated since 1894 to the children psychology, a theme on which she is self-taught and of which he will deal in many other writings (Colin, 2005). It is therefore not surprising that Paola's attention is focused on children, that observe to capture their peculiarities and ability to enhance and stimulate, the desire to give support to the creativity of children teirselves. Paola prusue this aim. Not only through the production of children's books, but also through the development of a magazine project dedicated to small readers, with a cheerful and funny cut, to accompany the child towards the pleasure of reading. This is the reason why it was founded It the project of "Corriere dei Piccoli», an insert in the newspaper "Corriere della Sera», which will represent the first weekly magazine of comics in Italy, published from 1908 to 1996 for over 4,500 issues divided into 88 years (Lollo, 2009).

The project as developed by Paola Lombroso thanks to a careful examination of the production for foreign children, despite finding the interest of publishers, is not entrusted to Paola Lombroso herself as a woman. Despite the bitterness of Lombroso in seeing her idea pass into the hands of others, when the new magazine for children sees the light in December 1908, she agrees to continue a limited collaboration dealing with the section Correspondence in which he signs with the pseudonym of zia Mariù. The literary skills, the direct and affectionate style, the irony that underlie his writings allow Lombroso to soon create a bond of trust and confidence with the young readers that will be the essential basis for the initiative of the rural Library, core of this study.

In fact, a letter from a rural school teacher addressed to Correspondence starts the initiative that will see zia Mariù becoming the reference point of generations of children who discover how self-confidence, the search for its strengths and its mobilization can lead to tangible results, helping to solve endemic problems such as those of rural school in Italy in the early twentieth century where the shortage of resources - economic, educational, structural, magistralis and so on (Montecchi, 2016; Pruneri, 2018) - placed its pupils at a serious disadvantage.

Here is zia Mariù's answer on the pages of the "Corriere dei Piccoli» of July 1909 that mark the beginning of the initiative:

There's a question for help. That's what it's about. A teacher Liduina Valz of Riabella Balma (Biellese) writes me asking me to interest my children to send books for the library of his school [...]. To enrich with some books at least the rural schools has always been one of my dearest dreams. And here's what I propose now. All the children must this summer try somehow to collect some money to 
buy books to send not only to the school of Riabella Balma but to all the others that you can, 10 volumes per school. But you must earn this money from you, with some work. I do not exclude lotteries and charitable performances for those who know how to organize them but I would ask the adults to think of some other means of earning money, without appealing to charity, doing a job (Fava, 2016, p. 170).

This first call to action shows how the initiative is far removed from a mere action by benefactor or simple offer by the wealthiest children towards the poorest or unlucky ones, but it is configured as a real activation. Lombroso has confidence in children and in their abilities and intends to strengthen precisely this trust to crown his desire to spread the pleasure of reading, in order to make "to fall in love with easy and pleasant books [children], who rightly distrust reading, imagining that it offers no other treasures than boring school books» (ibid).

After the start of the project through the Correspondence pages of «Corriere dei Piccoli», when the fracture with publishers becomes too harsh - also because of the success of this same project that publishers accused of occupying too much space - zia Mariù interrupts any collaboration with the "Corriere dei Piccoli». Nevertheless she keeps his rural school library project alive. Simply change the tool of the initiative, creating the aforementioned "Bollettino delle bibliotechine rurali», published by Paola Lombroso itself since 1912, based at her home in Turin, Corso Peschiera.

\subsection{The structture of project "Bibliotechine per le scuole rurali"}

In her writings Paola Lombroso outlines the two founding points of the initiative. The first one was to bring the book "right where no book could otherwise go, where the forgotten and lost school children are" (Carrara Lombroso, 1912b, p. 13). It is therefore a question of using the book as a tool not only of culture but also for social inclusion, not to leave anyone behind, not to forget those pupils of about 8,000 rural schools present on the Italian territory that were devoid of any furniture, teaching aid and book. On one hand, Lombroso's social and political thinking emerges and on the other the confidence in the role of the book within the path and children development.

The choice of books must be inclusive too: it has to offers an initial overview of the various literary genres that can delight the young reader but also does not make children who barely read and know little of the Italian language feel alienated or rejected, in favour of dialect. This emerges from the list of books selected by zia Mariù as mandatory in her school libraries that she gave to rural schools: 
I believe it is indispensable that in this collection of volumes there is a volume of folkloric fairy tales (that is, those fairy tales such as Cinderella, Little Red Riding Hood, etc., found in all dialects) because you have to think that all children in rural schools speak dialect and learn Italian almost like a foreign language. We must therefore offer them a book of which they are familiar with the subject, which will help them to translate, to understand words and phrases. And fairy tales are a centuries-old heritage, traditional of every dialect and that everyone knows for having heard them told by grandmothers, as companions and serve very well for it. To the book of fairies I immediately add Pinocchio [...] which has such a nice and fantastic content. Of course I want all my libraries to have Heart which is a national book of Italian children and contains a whole small childhood humanity, many types and events of children that interest and excite [...]. To these three books I can add others: La Capanna dello Zio Tom, La vita di Pulcinella, Le avventure del Barone di Munchausen, La vita militare written by De Amicis, Le Fiabe written by Capuana and Emma Perodi, Minuzzolo, Giannettino. In short, books that for strange adventures or for the familiar things they treat can be passionate. To each of these libraries I would like to join one more anthology - Fior da Fiore written by Pascoli - because if a few more open minds are among the small rural readers of the library, they may have a wider horizon (Carrara Lombroso, 1912b, pp. 5 e 6).

We can see a knowledge both of the development of the child's mind and of the literature for childhood that is selected through a principle that we could say of gradualness, passing from books that the child feels as closer to himself, and then accompany him to wider boundaries. At the same time, the choice of books reveals Lombroso's positivist and socialist convictions where culture is an instrument of growth and that there is no room for social immobility: even among children less trained by school you can find a brilliant and curious mind. Zia Mariù's libraries, which were provided free of charge to rural schools, had an initial endowment of 10 books: to these five carefully selected were added five from donations.

The second founding principle of the initiative is based on the fact that «Instead of exciting children to give money, I have always tried to excite them to earn it, doing something, because children are much more interested in a work they have worked on personally, in which they are actors rather than mere spectators» (Carrara Lombroso, 1912b, p. 7).

Far from the charitable educational actions developed in nineteenth-century society (Chiosso, 2007; Caimi, 2018), Lombroso in the early twentieth organizes a real action of civic prominence in which everyone is called to mobilize and participate to achieve a common goal that affects the whole society.

The Bibliotechine project for rural schools embodies the concept of "taking charge" of a problem and committing oneself to the common good, exactly what we now call active 
citizenship (Moro, 1998). Zia Mariù is strongly convinced that «a work, however good, in order to be vital, must not rely above all on charity but must know how to find means of subsistence» («Bollettino delle bibliotechine rurali»,6, 2, p. 3). The principle is clear: «do not beg, offer something in exchange for the ten cents that you receive, to obtain the material of books that the scoletta wants with a job, not with a supplication» (ibid.).

The pages of the "Bollettino delle bibliotechine rurali» allow us to follow year by year the growing success of the initiative and to observe the different strategies that children had put in place to earn some money to invest in libraries to donate to rural schools: those who grew silkworms, who washed cars, who cooked cakes, offered flowers, who sold calendars or almanacs, who made placemats, who organized lotteries and parties and much more. Among all these initiatives the best known is that of coloring postcards to sell, postcards which basic drawings were made by artists and painters friends of Paola Lombroso and then made in multiple copies that were sent to children to start coloring: in 1911 "zia Mariù's children" had painted 20,000 postcards (Carrara Lombroso, 1912b). A third principle, that today we will call engagement, is added in itinere, suggested almost casually according to what declares Paola Lombroso by the children themselves: the child who has committed himself to donate a library gets the right to name it after a loved one and assumes the role of "patron" of the library itself. $\mathrm{He}$ is a kind of protector/benefactor who, thanks to the triggering of a process of gratitude on the part of the pupils receiving the gift, will continue to feel bound and to commit to enrich the library or otherwise support the school of which he became patron. This trick allows to transform what could be an improvised action of opening a library in a sustainable project on the term.

\subsection{The structure of the project's broadcasting channel: the «Bollettino delle bibliotechine rurali»}

The success of the initiative is such that after the first four months of "fundraising" the first 10 libraries are donated in November 1909 and after three years the strength of the joint action leads to achieve the result of the successful distribution of 650 libraries (Carrara Lombroso, 1912a).

When the publication of the "Bollettino delle bibliotechine rurali» starts in 1912, therefore, the size of the project is such as to have to organize the collection of money and the distribution of books in working groups divided by territory: zia Mariù was directly responsible for the Turin group and her colleagues managed the activities of the groups in Rome, Milan, Venice, Palermo, Brescia and Florence, of which the "Bollettino delle bibliotechine rurali» presents as a communication tool. 
The structure of the Bulletin provides for a first part in which each territorial "group leader" illustrates which and how many libraries have been sent. Then find space the letters sent by the project's patrons and collaborators, which bring their ideas and show how they contributed to the project. Then we there are the Zia Mariù's answers to requests or questions received by mail. They never lack a reference to the financing method linked to the coloring of the postcards. The pages of the «Bollettino delle bibliotechine rurali» close with information related to competitions that were often held to encourage fundraising (as an example in «Bollettino delle bibliotechine rurali» n. 2 of October 1912, reference is made to a competition about the better painted postcards) and the Dlin dlin column where the money received and expenses were meticulously accounted. Sometimes were added short reviews of children's books which the «Bollettino delle bibliotechine rurali» suggested to its young readers. There is no lack of communications about Conferences, Exhibitions, Lectures attended by zia Mariù, on the occasion of which she illustrated the initiative. As an example, in "Bollettino» n. 5-6 of December 1912, there is the "Congress of Culture" speech in Rome in which zia Mariù proudly illustrates the numbers of Bibliotechine and explains how the volumes directly donated have reached the amount of 7,500 books. If you also count the books donated at a later time by the "patrons", the total number of donated book get to 30.000 (Ivi, p. $\mathrm{VI})$. The rapporteur then claims the contribution that the initiative of libraries has given to the development of popular culture: zia Mariù is aware that in Italy exist in the same years Consortia and Institution that are responsible for providing schools with library but for a fee:

so in the most miserable schools, more forlorn and abandoned, those where in a single classroom are piled 100,105, 124 children - unique mixed school of three classes with a single teacher, paid many times 40 but also 35 or 30 lire a month! the benefit of a library is forbidden. These are municipalities so poor that they can not pay the locals and they must resign themselves to a single mixed school of three classes because they can not pay two teachers, let alone if these countries can give themselves the luxury of a library that costs 40 or 50 lire! [... ] It is a small glory for our libraries to have been the first to bring the book in some poor school and in the remote countries of Italy, hours and hours away from a railway line, where the post does not reach only two days a week (Ivi).

Finally, these sections of the "Bulletin» in which can be found the reports of zia Mariù held on the occasion of conferences, show us how Paola Lombroso was aware that another element that contributed to the success of the initiative was to present it as something not compulsory but spontaneous, not imposed by the Director or the School Inspector: "Ours libraries have born such miraculous fruits because they are articulated by every official gear, by every bureaucratic noose". In this way the teacher who chose to apply for the library did so by choice, feeling sincere interest and consequently being oriented to really use the library with its students, outside of any obligation. Finally zia 
Mariù in public presentations as well as in the "Bulletin» in which there are transpositions, does not hide the economic difficulties of carrying forward a project of this scope, whose budget is "really not in balance":

I then hated the word and the thing "charity", I wanted to create for my libraries an organization that would make it independent from charity and not be coercive for anyone. Here's how I do it: in exchange for the money I need (and I need it a lot for the shipments, for the purchase of books, for the bindings!) I offer something, a product, a commodity that has on the market the value I ask for it.

It is therefore sufficient to scroll through the list of headings that constituted the "Bulletin» in order to understand how much it and the whole initiative it represents are based on a transparent communication, in which everyone is informed of everything, in which each contribution finds space and is valued and in which the recipients of the Bulletin are directly involved, establishing a biunivocal channel between recipients and protagonists. The pages of the periodical are then occasionally integrated with a section of thanks and a dedicated to the "iconography of libraries" that is to publish the drawings of the children involved in the initiative who want to depict the initiative itself or moments of it (for example: the arrival of mail in a rural school).

\subsection{Content and lines of inquiry}

Reading the contents of the letters published, which are often titled by Zia Mariù in a manner very consistent with the issues addressed within them, and the analysis of the texts of the other sections show a large amount of data that offer an insight into the historical reality of the period. The "Bollettino delle bibliotechine rurali» is thus transformed into a source. Certainly it is a source to specifically reconstruct the initiative of the rural libraries (which allows to do with great precision, as we have seen) but it is also a source for several other topics of investigation.

From the pages of the Bulletin it is possible to extrapolate information to study from a historical point of view:

- the production of children's books, thanks to the presentations made by zia Mariù on the pages of the magazine;

- children's publishers, present not only through the literary novelties of zia Mariù but also through episodes and donations that are reported in the section of the initial report or the different congresses;

- the figure of the teacher, often cited by zia Mariù who reports the exchange of letters, from which emerge the professional and even personal conditions related to the status of a rural school teacher; 
- the reality of rural schools from the point of view of location, conditions, buildings, furnishings and teaching aids that always emerge from the letters of teachers and pupils;

- Pedagogical Congresses and Exhibitions, presented by zia Mariù on the pages of the periodical;

- iconography aspects related to children's literature, which emerge thanks to the nods to the competitions held through the Bulletin, the production of coloring cards and the collaboration of some of the most famous illustrators of the period (just mention Golia or Mussino);

- the presence of charities, consortia and organizations that promoted culture and education for the most disadvantaged children, together with assistance, which are mentioned in various letters;

- personality traits of children's writers or personalities of the cultural life of the country who maintained relations with the initiative of zia Mariù to which they often contributed with initiatives and correspondence reported on the pages of the Bulletin.

But the most striking aspect of the Bulletin is communication: the Bulletin as an optimum communication tool, perfectly suited to the objectives of the project and its structuring. It presents itself as a direct and open channel of communication, of exchange, of updating, but also as a place where everyone finds his space and his valorization. At the same time, the Bulletin knows how to perfectly restore the key points of the project, showing all its design strength at the base of which there is a strong civic activation, a call to protagonism.

In fact, it reveals very well how the project is not limited to being a - although important - action to spread reading, but also on the one hand of civic prominence, on the other side of inclusion and democratization of culture, enabling pupils in schools with fewer resources to have equal opportunities to that of richer schools and, finally, to create links between different schools and pupils who are also distant from each other.

\section{Discussion: the communication power of «Bollettino delle bibliotechine rurali»}

The analysis of the pages of the Bulletin allows us to fully understand the role of communication as an element of the success of the initiative conceived by Paola Lombroso. Consequently, the role of this communication tool - the Bulletin - has been fundamental. It is a faithful reflection of the approach of the entire project and therefore 
of the educational pedagogical thought of Paola Lombroso that underlies it. By analyzing the communicative aspects, one is able to grasp the way of Lombroso to see childhood and to relate with.

It is not secondary to try to explain the main features, just to know in depth on one side Paola Lombroso and the other the deep identity of this initiative.

In order to highlight them, each of these communicative aspects will be reported in a list in which the feature itself is followed by a brief illustration of how Paola Carrara Lombroso declined within her project dedicated to the library of rural schools:

- the immediate response of the child's commitment: every child engaged in the fundraising initiative for the creation of Bibliotechine for rural schools had an immediate and tangible feedback of the results: not only they did the activities conceived and carried out turn into real money, but such money was publicly counted by zia Mariù on the pages of the "Bollettino delle bibliotechine rurali» in the column "Dlin dlin" specifying the name of the person who paid them. This is a public recognition. Even more powerful is the strategy of zia Mariù to "celebrate" officially the child who engages in this civic initiative by making the kid to become "patron" of the library that gives away: therefore she assumes an official and imperishable role, recognized by all users of the library. The patron also had the task of providing each book with the writing that would recall his name as a donor, thus extending the duration of the donation action: every student who takes over the book will ideally know his patron. This is an explicit recognition that nourishes recognition by the beneficiaries: soon the pupils of schools to which the library was donated sent letters, thanks and small gifts to their patron, thus making tangible the feedback of the positive effects that its initial commitment had generated.

- offer the child a role and underline its importance: the figure of the "patron", who can (also choose who to dedicate the library he has given as well as those of "knights of the book" and "ladies of the palace") ensure that the pupil feels that he has a role and a specific task. The educational-educational strategy underlying it is evident and calls for role play and identification, accompanied by the attention of zia Mariù to always value these roles, emphasizing their strategic importance.

- feeding the child's self-esteem: zia Mariù manages to find space to quote, praise and thank every single child who engages in the initiative. She often does this by publishing in the "Bollettino delle bibliotechine rurali» phrases extracted directly from the communication received from the child. In this way the stimulus towards the pupil is twofold: he feel important because he is remembered with his name and surname, because his words, reported in the official journal of the project, are 
considered significant, however worthy of publication. A specific section entitled "The Praise of Children" aims to gratify children by emphasizing «all the various good qualities I found in children» («Bollettino delle bibliotechine rurali», II, 7, p. 6). These qualities are not at all childish but worthy of a wise adult: willingness, scrupulousness, firmness, universality, seriousness, trust, tenacity, punctuality. Alongside these reinforcements of the child's self-esteem, there is also an aspect of encouragement and support that invites everyone to believe in themselves and their abilities: «If he can, then we can all» («Bollettino delle bibliotechine rurali», III, 5, p. 5).

- to be able to enhance the individuality of the individual even in a collective action: connected to the previous point but different there is the ability of zia Mariù to return at the same time the global vision of the initiative and the individual, in which you can give the impression of knowing in depth and appreciating each individual employee. Her delicate descriptions of individual children («a delicate face, immersed in a halo of fine golden hair», («Bollettino delle bibliotechine rurali», II, 6, p. 5) allow everyone to feel a direct dialogue with Paola Lombroso, just as if she was addressing directly. Certainly the literary abilities of Lombroso are fundamental in this action, allowing her to use different adjectives and affectionate, often invented, that allow her to differentiate the messages. The result of this double vision exceeds the results that would be obtained with the use of only one of the two channels: zia Mariù manages to make the single child feel important within a great important action.

- not to belittle the idea of anyone but to facilitate the development: zia Mariù assumes a role as a coordinator-friend who does not place himself at a higher level or judge, but instead undertakes to encourage the ideas and contributions of each one. The invitation addressed to the child is always to find a concrete solution to achieve what it aims for, even if initially it may appear complex or impossible. Zia Mariù asks questions to the students who submit ideas, inviting them to find their own solutions. It does not replace them, it does not censor them, but on the contrary every little idea is recognized a great merit: "They were the most ready and wonderful children inventors, the tireless collaborators of this enterprise, and I had only the merit of following them, of ordering, of organizing what was in their minds and in their feelings" (Tiozzo, De Gasperi, Bottai, 2018, p. 52). Precisely this stimulus to autonomy and this trustful but discreet support of zia Mariù makes the children themselves train their own skills of analysis, evaluation and even selfassessment: "It was not my delicate and severe control, but the children's conscience was delicate and severe» («Bollettino delle bibliotechine rurali», 4, 3, p.4). 
- not to make anyone feel excluded: the success of the initiative soon puts zia Mariù in front of what could become a problem. In fact, the younger brothers of the Patrons, witnesses of the enthusiasm provoked by being protagonists of this "civic activation", also wish to take part in the project. But young people could often be an obstacle to self-financing actions for libraries. Zia Mariù manages to invent new roles adapted to the age of each according to age, ability, possibilities, inventiveness. The youngest girls, from 4 years old and up, take the name of Fairy benefices and through small shows help to collect money («Bollettino delle bibliotechine rurali», V, 17, p.4). According to Paola Lombroso, one of the secrets is precisely that of welcoming every contribution, indeed of «asking for very little effort ", ("Bollettino delle bibliotechine rurali», 6, 1, p. 1). At the same time it shows trust in each child, a sincere trust in the ability of each to identify «original and moving means» (Ibid.). This attention from Zia Mariù towards inclusion is rewarded by the sincere commitment of the children: «no one has ever abused my trust» («Bollettino delle bibliotechine rurali», 2, 2, p. 4).

- path that feeds itself: zia Mariù is aware that a peculiar feature of the success of this project is due to the virtuous circle that every action has triggered (Carrara Lombroso, 1912a). On one hand, the spontaneous start of correspondence and exchange of gifts between patron and school, has often encouraged the patrons not only to give the library as a gift but to follow it over the years, continuing to implement it. In this way the mobilization of children was not an isolated episode but has become a real modus operandi that accompanies the growth. At the same time, the project feeds itself thanks to the very satisfaction of children who become the best sponsors through a virtuous word of mouth: «The child speaks to his friends about the scoletta, the children, shows the postcards and explains the organization of the libraries: friends are encouraged to become patrons themselves» («Bollettino delle bibliotechine rurali», 5, 9, p.3). For children, even those new to the initiative, it is therefore absolutely normal to think about how to achieve some concrete action: no one turns to zia Mariù to ask to participate with simple gifts, but bringing ideas and proposals: «everyone started with accepting and trying, they are happy when they come to announce to me that they have done something» (Ivi).

- the project in which to involve children as a task of reality: zia Mariù while calling children does not refer to some abstract initiative but to tangible and measurable results. They are obtained through multiple tasks (cooking, organizing an event, keeping accounts...). These tasks are divided into two types: those that can be activated through personal and daily actions and those that instead involve other subjects in the project of the Library (artists, writers, publishers, businesses, ...) that make children feel part of an adult and mature society that, all together, cooperates and treats them as equals. 
- do not neglect the channel of communication: the project of ziat Mariù strength starts from its own communicative approach. First of all, communication as clear and comprehensible language, rich in information. Then communication as the creation of a place in which to share and value the results. In this sense, the «Bollettino delle bibliotechine rurali» was one of the keys to success by creating a showcase, a promotional channel to raise awareness of the initiative and attract more and more participants, but also to realize some of those strategic points such as offering public recognition to those who engaged; make the individual feel important and so on. Finally, communication because the "Bollettino delle bibliotechine rurali» soon became what we would call communities: a place for exchanging ideas, opinions, updates, requests, suggestions, reports. In the context of today's educational research, and in particular in the field of media education, the role of the "Bollettino delle bibliotechine rurali» could be considered such as a kind of collaborative platform to support a community of practice that grows together by engaging jointly around a theme of common interest (Rivoltella, 2019).

\section{Conclusions}

Through the presented points, it emerges how Paola Carrara Lombroso wanted to change society through the dissemination of children's books. Or better to allow everyone access to the pleasure of reading, going to support precisely the poorest schools. In reality, in Italy at the beginning of the 20th century, zia Mariù's initiative wasn't the only one in favour of the diffusion of school libraries and, more widely, children's literature. At last, a specific attention towards the child reader and the idea that reading could be not only strictly linked to learning or moral teachings, but also to entertainment, simple pleasure or even amusement (Boulaire, 2007; Bravo Villasante, 1983; Colomer, 1999) was starting to emerge at national and international level.

In 1904 Clara Archivolti Cavalieri created in Ferrara (later moved to Bologna in 1907) the Committee for the diffusion of school libraries with the aim of spreading libraries in elementary schools (Fiore, 2005). With the collaboration of the Municipality and some city personalities, this initiative promoted the establishment of small libraries for children, provided financial support and suggested books for children, so much so that in 1911 he published the first Catalogue of suggested books for children. In the meantime, in Milan, starting in 1903, on the initiative of the librarian Ettore Fabietti, a Consortium of Popular Libraries was set up, which included a section dedicated to children's literature (Fabietti, 1916). These initiatives preceded by a few years the creation in Turin by private citizens, such as Alberto Geisser, Paolo Boselli and Ildegarde 
Occella Trinchero, of the Provincial Consortium for Free Libraries in Elementary Schools, which aimed to provide schools with free books for reading (Pizzigoni, 2021).

This flourishing of initiatives by private citizens suggests the lack of a role for the State in promoting reading and school libraries. In fact, a decree of August 2, 1902 established school libraries in the rural schools (the same rural schools to which zia Mariù he will devote herself). The measure corresponds to little real action and when these libraries are opened they are in fact popular libraries (not for children), simply located in schools (Chilovi, 1903). The absolute absence of the State with respect to the diffusion of reading can be seen very well from the Corradini Inquiry that the Ministry of Education had promoted between 1907 and 1908 in order to have a picture of the situation of Italian schools. The report that follows this "census" shows how there was not really an entry dedicated to school libraries: the only references to books are inherent in the popular libraries that were often located at school sites and of which Corradini himself had to recognize "the deficiencies of the institution of popular libraries in Italy" (Corradini, 1908, p. 104).

Faced with the intervention of various private initiatives, that of Zia Mariù is not only the umpteenth attempt to support the development of children's literature or to help rural schools. It represents an absolute novelty, totally different from charitable or philanthropic initiatives to support reading or help poor schools. On the contrary, Zia Mariù directly involves the children, showing trust in them and in their abilities. And she does this by using effective and direct communication, capable of motivating and making everyone feel part of the same project. It is an action of communication and at the same time of civic activation that still today shows all its innovative capacity. Zia Mariù and her Bulletin are unique in the Italian panorama of the time and indeed remain so today. Certainly, first the World War and then a new school policy linked to the new Fascist ideas (which led to the Gentile Reform of 1923 which introduced a new focus on reading and the classroom library) gradually made the project lose its initial characteristics and consequently its strength. But nothing can obscure, in retrospect, the original character of the project, capable of truly bringing the child to the centre of the action.

It is hoped that new research on this topic will be initiated, perhaps by going directly to the school archives of those rural schools that had received zia Mariù's Library and that may preserve traces of exchanges of letters or of the life of the librarian herself. Or new private archives could emerge, perhaps - in the absence of Paola Lombroso's personal archive on the Bibliotechine project (Fava, 2004) - of some young "patron" who had contributed to the initiative. At the same time, an international comparison of similar initiatives of direct activation of children in favour of other children so that they can have access to the pleasure of reading could be very significant. Searching for links between projects, initiatives and personalities from different countries (Fouts, 1999; 
Hunt, 2015; Lerer, 2008) that, even in different historical periods, directly address children, and studying how they communicate with them, which registers they adopt and which tools could offer a cross-sectional view, can be useful to identify possible common threads in the relationship between children and the approach to reading.

\section{Bibliography}

Babini, V.P. (2008): "Paola Lombroso 1871-1954" in Numeri, atomi e alambicchi. Donne e scienza in Piemonte dal 1840 al 1960, Torino, Centro studi e documentazione pensiero femminile, vol. I, pp. 22-40.

Boulaire, C. (2007): «Les mutations de l'édition et de la presse jeunesse», in Mollier J.V. (dir.), Où va le livre, La Dispute, p. 129-155.

Bravo Villasante, C. (1983): Historia de la literatura infantil, Madrid, Doncel Editora.

Caimi, L. (2018): Carità educatrice: riscontri e testimonianze nell'Italia dell'Ottocento, Milano, Vita\&Pensiero.

Calcagni C. (1977), "Carrara Mario", in Dizionario Biografico degli Italiani, v. 20. By internet (02.09.2021): $\quad$ https://www.treccani.it/enciclopedia/mariocarrara (Dizionario-Biografico)/

Carrara Lombroso, P. (1912a): Elenco delle bibliotechine rurali zia Mariù, Firenze, Bemporad e Figlio.

- (1912b): L'aiuto dei bambini ricchi ai bambini poveri: biblioteche rurali di Zia Mariù, Varese, Tip. cooperativa Varesina.

Chilovi, D. (1903), Le librerie ambulanti. In Nuova Antologia, 63, pp. 463-480.

Chiosso, G. (2007): Carità educatrice e istruzione in Piemonte: aristocratici, filantropi e preti di fronte all'educazione del popolo nel primo ' 800 , Torino, SEI.

Colomer, T. (1999): Introducción a la literatura infantil y juvenil, Madrid, Ediorial Sintesis.

Colin, M. (2005): L'âge d'or de la littérature d'enfance et de jeunesse italienne. Des origines au fascisme, Caen, Presses universitaires de Caen.

Corradini, C. (1908): Relazione presentata a S. E. il Ministro della Pubblica Istruzione, Milano, Vallardi. 
Dolza, D. (1990): Essere figlie di Lombroso: due donne intellettuali tra '800 e '900, Milano, Franco Angeli.

Fabietti, E. (1916): Che cosa è una Biblioteca Popolare moderna. Milano: Federazione Italiana delle Biblioteche Popolari.

Fava, S. (2004): Percorsi critici di letteratura per l'infanzia tra le due guerre, Milano, Vita\&Pensiero.

- (2016): Piccoli lettori del Novecento. I bambini di Paola Carrara Lombroso sui giornali per ragazzi, Lecce, Pensa MultiMedia.

Fiore, M. (2005): Clara Cavalieri Archivolti: un progetto a favore delle biblioteche scolastiche e della lettura per l'infanzia, Verona, Zetadue.

Hunt P. (eds.) (2015): Understanding Children's Literature, New York, Routledge

Lerer S. (2008): Children's Literature: A Reader's History, from Aesop to Harry Potter, Chicago-London, The University Press of Chicago.

Lollo, L. (eds) (2009): I/ Corriere dei piccoli in un secolo di riviste per ragazzi: atti del Convegno (Università Cattolica del Sacro Cuore di Milano, 28 marzo 2008), Milano, Vita\&Pensiero.

Montecchi, L. (2016): I contadini a scuola. La scuola rurale in Italia dall'Unità alla caduta del fascismo, Macerata, EUM.

Moro, G. (1998): Manuale di cittadinanza attiva, Roma, Carocci Editore.

Pizzigoni, F.D. (2021): "Torino 1893-1906. Precoci sperimentazioni per la creazione di biblioteche per ragazzi" in Ricerche di Pedagogia e Didattica - Journal of Theories and Research in Education 16, 1, pp. 191-204.

Pruneri, F. (2018): "Pluriclassi, scuole rurali, scuole a ciclo unico dall'Unità d'Italia al 1948" in Diacronie. Studi di Storia Contemporanea, XXXIV, 1, pp. 1-25.

Rivoltella, P.C. (2019): Media education: idea, metodo, ricerca, Brescia, Scholé.

Simone, S. (2020): "Paola Lombroso e Zia Mariù: l'ispirazione socialista negli scritti sull'infanzia e per l'infanzia" in Forum Italicum: A Journal of Italian Studies, LIV, 1, pp. 331-353.

Tiozzo, M.G. - De Gaspari, I. - Bottai, A. (2018): La Casa del Sole: storia di una istituzione torinese, Torino, Città di Torino. 